\title{
Requirements for, and Cytoplasmic Concentrations of, Sulphate and Chloride, and Cytoplasmic Volume Spaces in the Halophilic Bacterium Ectothiorhodospira mobilis
}

\author{
By JOHANNES F. IMHOFF* AND THOMAS RIEDEL \\ Institut für Mikrobiologie, Rheinische Friedrich-Wilhelms-Universität, Meckenheimer Allee 168, \\ D-5300 Bonn 1, FRG
}

(Received 17 June 1988; revised 29 August 1988; accepted 17 October 1988)

\begin{abstract}
Ectothiorhodospira mobilis is a halophilic phototrophic bacterium that has been isolated from soda lakes containing high concentrations of sulphate, chloride and carbonates. It utilizes reduced sulphur compounds as photosynthetic electron donors and oxidizes them to sulphate, but can also grow photoheterotrophically with sulphate as sole sulphur source. The requirements for, and the cytoplasmic concentrations of, sulphate and chloride have been determined. High concentrations of sulphate are neither required for nor inhibit growth. Although chloride is by far the dominant anion of the environment, growth of $E$. mobilis occurs in the absence of added chloride. Sodium chloride can be replaced by sodium sulphate and sodium carbonate. Chloride is excluded from the cytoplasm with decreasing ratios of cytoplasmic/external chloride at increasing external chloride concentrations (under iso-osmotic conditions).
\end{abstract}

\section{INTRODUCTION}

Ectothiorhodospira mobilis strain $51 / 7$ is an alkaliphilic, halophilic phototrophic bacterium isolated from alkaline brines of the Wadi Natrun in Egypt. These brines have characteristically high concentrations of sodium, sulphate, chloride and carbonate ions, but lack significant concentrations of divalent cations (Imhoff et al., 1979).

The ionic composition of natural brines appears quite important and selective for the kind of bacteria that will develop. We found mass developments of halobacteria in the brines of the Wadi Natrun and proposed that these halobacteria cannot have a requirement for high concentrations of divalent cations (Imhoff et al., 1979), a general property of the 'classical' halobacteria, and this has been experimentally confirmed (Soliman \& Trüper, 1982). In contrast, halobacteria from the Dead Sea, a lake with extremely high concentrations of magnesium and calcium ions, require higher concentrations of these divalent cations compared to classical halobacteria isolated from marine salterns and habitats with a similar ionic composition (Cohen et al., 1983; Mullakhanbhai \& Larsen, 1975).

Among the halophilic phototrophic purple bacteria two groups can be distinguished on the basis of their ion requirement (see Imhoff, 1988a). Halophilic Rhodospirillum species, which are dominant in marine salterns, grow well in media at neutral $\mathrm{pH}$ and an ion content typical of marine waters, including considerable concentrations of divalent cations (Drews, 1981; Nissen \& Dundas, 1984; Rodriguez-Valera et al., 1985), whereas the halophilic Ectothiorhodospira isolates bloom in hypersaline soda lakes and require growth conditions that prevent the solubility of calcium and magnesium salts.

Ectothiorhodospira mobilis strain $51 / 7$ grows optimally at $5 \%, \mathrm{w} / \mathrm{v}$, salinity in the standard medium (equivalent to $780 \mathrm{~mm}$-sodium). It does, however, tolerate extremely high salt concentrations up to $20 \%$, w/v, salinity. It is not known whether this bacterium has a specific requirement for the anions that are present at high concentrations in the environment. In this study we have analysed the requirement of $E$. mobilis for sulphate and chloride, the cytoplasmic 
concentrations of these ions and changes of the cytoplasmic volume dependent on ion concentrations and osmotic conditions.

\section{METHODS}

Bacteria and media. Ectothiorhodospira mobilis strain 51/7 was isolated from hypersaline soda lakes of the Wadi Natrun in Egypt. Other strains of Ectothiorhodospira mobilis and Ectothiorhodospira halophila have been isolated from the same environment and are maintained in culture in our laboratory. Ectothiorhodospira vacuolata DSM 2111 was isolated from a salt swamp in Jordan (Imhoff et al., 1981). The medium described for the cultivation of Ectothiorhodospira species by Imhoff \& Trüper (1977) was used as modified by Imhoff (1988b) with the concentration of sodium acetate reduced to $1 \mathrm{~g} \mathrm{l}^{-1}$. The basal medium has the following composition $\left(\mathrm{g} \mathrm{l}^{-1}\right.$ for a medium with $5 \%$, w/v, salinity): $\mathrm{KH}_{2} \mathrm{PO}_{4}, 0 \cdot 8 ;$ sodium acetate, $1 \cdot 0 ; \mathrm{Na}_{2} \mathrm{~S}_{2} \mathrm{O}_{3} .5 \mathrm{H}_{2} \mathrm{O}, 1 \cdot 0 ; \mathrm{NaCl}, 30 \cdot 0 ; 1 \mathrm{M}$-sodium carbonate ( $\mathrm{pH} \mathrm{9.0)}, 200 \mathrm{ml}$; trace element solution SLA, $1 \mathrm{ml}$ (Imhoff \& Trüper, 1977).

The components were dissolved in $600 \mathrm{ml}$ distilled water and the carbonate buffer was added. The volume was adjusted to $980 \mathrm{ml}$ and this solution was autoclaved. The salinity was adjusted to the desired value by variation of the $\mathrm{NaCl}$ content (assuming a contribution of $2 \%, \mathrm{w} / \mathrm{v}$, by the other medium constituents). The remaining salts were sterilized separately and added with gentle stirring after cooling to room temperature $\left(\mathrm{ml} \mathrm{l}^{-1}\right): 2 \%, \mathrm{w} / \mathrm{v}$, $\mathrm{MgCl}_{2} .7 \mathrm{H}_{2} \mathrm{O}, 5 ; 1 \%$, w/v, $\mathrm{CaCl}_{2} .2 \mathrm{H}_{2} \mathrm{O}, 5 ; 5 \%$, w/v, $\mathrm{Na}_{2} \mathrm{~S} .9 \mathrm{H}_{2} \mathrm{O}, 5-10 ; 20 \%$, w/v, $\mathrm{NH}_{4} \mathrm{Cl}, 4$. The medium was then distributed into sterilized culture vessels, which were filled completely with only a small air bubble left. Before inoculation they were preincubated at the incubation temperature to achieve volume expansion and then inoculated with exponentially growing cultures of $E$. mobilis strain $51 / 7$. For 'chloride-free' media (containing about $0.4 \mathrm{mM}$-chloride), $\mathrm{NH}_{4} \mathrm{Cl}, \mathrm{CaCl}_{2}$ and $\mathrm{MgCl}_{2}$ were replaced by equivalent molar concentrations of $\left(\mathrm{NH}_{4}\right)_{2} \mathrm{SO}_{4}, \mathrm{CaCO}_{3}$ and $\mathrm{MgSO}_{4} ; \mathrm{NaCl}$ was replaced iso-osmotically by $\mathrm{Na}_{2} \mathrm{SO}_{4}$.

For photoheterotrophic growth of $E$. mobilis reduced sulphur compounds were omitted and $0 \cdot 1 \%, w / v$, sodium ascorbate was added to achieve anoxic conditions. Under these conditions sulphate was used as sole sulphur source.

Culture conditions. Stock cultures were grown in $50 \mathrm{ml}$ screw-capped bottles in the light (about $6000 \mathrm{~lx}$ ). Growth experiments were done in a 11 glass fermenter under nitrogen gas at constant temperature $\left(37^{\circ} \mathrm{C}\right)$ and total light irradiance of either 60000 or $120000 \mathrm{~lx}$ illumination at the surface of the fermenter.

Protein determination. Protein was determined by the Lowry method. To remove interfering coloured pigments the cells were centrifuged at $5000 \mathrm{~g}$, the pigments extracted with ice-cold acetone/methanol $(7: 2, \mathrm{v} / \mathrm{v})$, and again centrifuged. The pellet was dried and redissolved in distilled water for the protein assay.

Determination of the cytoplasmic volume. Determination of cellular volume spaces was done according to Stock et al. (1977) and Rottenberg (1979). Samples of a cell suspension were incubated with three different radioactive marker molecules for the various spaces: the cytoplasm, the extracellular space (outside the outer membrane), and the total water space. ${ }^{3} \mathrm{H}_{2} \mathrm{O}\left(1 \mu \mathrm{Ci} \mathrm{mmol}^{-1} ; 37 \mathrm{kBq} \mathrm{mmol}^{-1}\right)$ was used for the total water space, $\left[{ }^{14} \mathrm{C}\right] \operatorname{dextran}(370$ $\left.\mu \mathrm{Ci} \mathrm{g}^{-1} ; 13.69 \mathrm{MBq} \mathrm{g}^{-1}\right)$ for the extracellular space, and $\left[{ }^{14} \mathrm{C}\right]$ sorbitol $\left(302 \mathrm{mCi} \mathrm{mmol}^{-1} ; 11 \cdot 17 \mathrm{GBq} \mathrm{mmol}^{-1}\right) \mathrm{for}$ the extracytoplasmic space. As determined by control experiments, neither sorbitol nor dextran were taken up by the cells or bound to the cell envelope. The commercial dextran was dialysed prior to use in order to remove low- $M_{\mathrm{r}}$ components. For analysis of the influence of salinity and $\mathrm{pH}$ on cytoplasmic volumes and for determination of the cytoplasmic sulphate concentrations, late-exponential-phase cultures $(100 \mathrm{ml})$ were centrifuged, resuspended and concentrated about 10-fold (up to a concentration of $4 \mathrm{mg}$ protein $\mathrm{ml}^{-1}$ ) in fresh medium. This suspension was kept under nitrogen gas at $37^{\circ} \mathrm{C}$ and was illuminated $(6000 \mathrm{~lx})$ until used for volume determination.

To $1.4 \mathrm{ml}$ of this suspension $10 \mu \mathrm{l}$ each of $\left[{ }^{14} \mathrm{C}\right]$ sorbitol and unlabelled sorbitol (to a final concentration of $1 \mathrm{~mm}$; $146 \mu \mathrm{Ci} \mathrm{mmol}{ }^{-1}$ ) was added. Separate samples of $1.4 \mathrm{ml}$ of the same cell suspension were treated in a similar manner with ${ }^{3} \mathrm{H}_{2} \mathrm{O}$ and $\left[{ }^{14} \mathrm{C}\right]$ dextran. The suspensions were incubated for $5 \mathrm{~min}$ and samples $(450 \mu \mathrm{l})$ were then centrifuged in a Beckman Microfuge through silicone oil of appropriate density in Eppendorf reaction vessels containing $120 \mu 115 \%, v / v$, perchloric acid and $650 \mu$ l silicone oil. After separation samples $(80 \mu l)$ were taken from the medium supernatant above the silicone oil layer and, after careful removal of the remaining supernatant and the silicone oil from the perchloric acid fraction, counted in a liquid scintillation counter. The medium supernatant was mixed with an equal volume of $15 \%, \mathrm{v} / \mathrm{v}$, perchloric acid and the perchloric acid sample was mixed with an equal volume of medium to obtain identical quenching in the scintillation counter.

For good separation it was necessary to adjust the density of the silicone oil to the density of the medium, which varied with salinity. The silicone oil from Serva DC 550 (density $1.07 \mathrm{~g} \mathrm{ml}^{-1}$ ) was suitable for cells in $5 \%$, w/v, salinity medium. For cells suspended at higher salinities this oil was mixed with bromobenzene (density $1.49 \mathrm{~g}$ $\mathrm{ml}^{-1}$ ) to achieve suitable densities.

The cytoplasmic volume was determined by subtracting the sorbitol space from the total water space, the total cellular space by subtracting the dextran space from the total water space, and the periplasmic volume by subtracting the dextran space from the sorbitol space according to the equation given by Rottenberg (1979). In 
experiments with high cell densities the volume of the perchloric acid phase was corrected by addition of the penetrated total water space.

Cell suspensions which were not concentrated were used to determine the influence of the growth phase on cytoplasmic volumes and to determine these volumes for calculation of cytoplasmic chloride concentrations. For these determinations $100 \mu \mathrm{l}$ each of ${ }^{3} \mathrm{H}_{2} \mathrm{O},\left[{ }^{14} \mathrm{C}\right]$ sorbitol (final activity $146 \mu \mathrm{Ci} \mathrm{mmol}{ }^{-1}$ ) and $\left[{ }^{14} \mathrm{C}\right]$ dextran were added, respectively, to $3.0 \mathrm{ml}$ samples of the culture. Samples $(1 \mathrm{ml})$ of these suspensions were used with $120 \mu \mathrm{l}$ perchloric acid and $800 \mu \mathrm{l}$ silicone oil in $2.2 \mathrm{ml}$ reaction vessels and treated as described above. All volume determinations were done in triplicate and mean values were used for the calculations.

Determination of cytoplasmic ion concentrations. Identical cell material was used for ion determination and determination of the cytoplasmic volume and both samples were treated in parallel. After centrifugation through silicone oil into a lower phase of perchloric acid, the material of this phase from several tubes was collected and recentrifuged to separate particulate matter. The inorganic ions were determined in the perchloric acid phase and in the medium supernatant. It was assumed that the ion concentrations in the medium and in the periplasmic space are identical. The amount of ions present in the extracytoplasmic space was subtracted from that in the total water space that passed the silicone oil. The remainder represents the amount present in the cytoplasm.

Determination of chloride. This was done using an ion-sensitive electrode (Orion model 94-17B). Measurements were taken with a millivoltmeter (Knick, model 741) at constant ionic strength $\left(100 \mathrm{~mm}-\mathrm{NaNO}_{3}\right)$. Interfering effects of sulphide and thiosulphate were avoided by oxidation of these compounds with hydrogen peroxide $(400 \mu \mathrm{l}$ $30 \%, \mathrm{v} / \mathrm{v}, \mathrm{H}_{2} \mathrm{O}_{2}$ were added to each $10 \mathrm{ml}$ sample and stirred for $10 \mathrm{~min}$ prior to the measurement). Samples containing perchloric acid were neutralized on ice with ice-cold $10 \mathrm{M}-\mathrm{KOH}$ and the precipitated potassium perchlorate was removed by centrifugation. A calibration curve was measured with $\mathrm{NaCl}(0.05-100 \mathrm{~mm})$ under identical conditions.

Determination of sulphate and other sulphur compounds. Cytoplasmic sulphate concentrations were determined with concentrated cell suspensions centrifuged through silicone oil under conditions identical to those used for the volume determination. The sulphate concentration of the perchloric acid fraction was measured. Sulphate was determined turbidometrically as $\mathrm{BaSO}_{4}$ according to Dodgson (1961). Calibration was necessary with each measurement. Values from $40-500 \mathrm{nmol}$ sulphate per assay were used as standards. Sulphide was determined according to Pachmayr (1960), elemental sulphur according to Bartlett \& Skoog (1954), thiosulphate according to Urban (1961), and total sulphur as sulphate according to Novozamsky \& van Eck (1977).

\section{RESULTS}

\section{Reduced sulphur sources}

Sulphur plays an important role in the metabolism of Ectothiorhodospira mobilis, which utilizes sulphide and thiosulphate as photosynthetic electron donors and forms sulphate as the final oxidation product. During oxidation of sulphide extracellular elemental sulphur is formed as an intermediary product (Trüper, 1968). Oxidation rates and oxidation products were analysed in cultures grown phototrophically with $0.8 \mathrm{~mm}$-sulphide, $3.8 \mathrm{~mm}$-thiosulphate and $1 \mathrm{~mm}$-acetate in a 11 glass fermenter. Sulphide was oxidized rapidly and completely consumed after $90 \mathrm{~min}$. At this time the elemental sulphur concentration reached its maximum $(0.75 \mathrm{mM})$. The oxidation of elemental sulphur proceeded slowly and was incomplete even after $11 \mathrm{~h}$. The oxidation of thiosulphate proceeded more slowly, but in the stationary phase thiosulphate was also completely oxidized. Both the sulphane and the sulphone sulphur moieties of thiosulphate were oxidized to sulphate. The initial sulphate concentration in the medium was $1.6 \mathrm{~mm}$ and increased during growth to about $8.6 \mathrm{~mm}$ as a consequence of the oxidation of sulphide and thiosulphate (Fig. 1). The experimental determination of total sulphur (according to Novozamsky \& van Eck, 1977) showed values between 9.4 and $9.8 \mathrm{~mm}$, which is in good agreement with the sum of the values for sulphate, sulphide, thiosulphate and elemental sulphur. The slightly lower final concentration of sulphate may be due to the presence of small amounts of elemental sulphur and polysulphides and also to a small amount of sulphur assimilated by the cells.

Due to these dissimilatory oxidation processes it was not possible to maintain a constant sulphate concentration under these culture conditions. The concentration of sulphate continuously increased during growth with reduced sulphur sources. It was, however, possible to omit sulphate from the culture under these conditions. These data indicate that high sulphate concentrations are not required by $E$. mobilis strain $51 / 7$. Similar results were obtained with other strains of E. mobilis, E. halophila and E. vacuolata. 


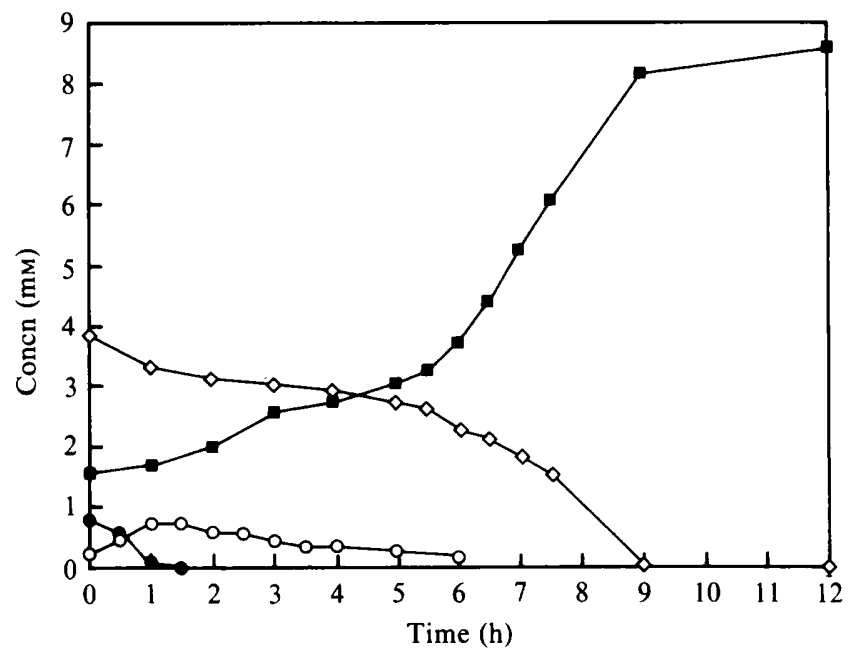

Fig. 1. Oxidation of reduced sulphur compounds, sulphide $(\odot)$, thiosulphate $(\diamond)$ and elemental sulphur $(O)$, to sulphate $(\square)$ by a growing culture of Ectothiorhodospira mobilis strain $51 / 7$. Cells were grown in a 11 glass fermenter in the standard medium with $5 \%$, w/v, salinity $\left(\mathrm{pH} \mathrm{9.0)}\right.$ at $37^{\circ} \mathrm{C}$ and with $60000 \mathrm{~lx}$ illumination.

\section{Sulphate as sole sulphur source}

E. mobilis is not dependent on the presence of reduced sulphur sources for growth, but was able to assimilate sulphate as sole sulphur source. Under these conditions the sulphate concentration in the growth medium can be controlled; organic substrates (here acetate) serve as photosynthetic electron donors and sodium ascorbate $(0 \cdot 1 \%$, w/v) can be used to maintain anoxic conditions.

In order to determine the growth requirements of E. mobilis for sulphate and chloride and to measure effects of the ions, but to exclude influences of the osmolarity, $\mathrm{NaCl}$ was replaced isoosmotically by sodium sulphate. Compared to results obtained using the $10 \%$, w/v, standard medium without sulphate (with $1.37 \mathrm{M}-\mathrm{NaCl}$ ), the iso-osmotic increase of the sodium sulphate concentration up to $800 \mathrm{mM}$ with the concomitant decrease of the $\mathrm{NaCl}$ concentration did not significantly alter the growth response (on the basis of protein yield). A further increase of the sulphate concentration of $880 \mathrm{~mm}$, however, reduced cell yield by about $15 \%$.

It can therefore be concluded that high concentrations of sulphate are not required by $E$. mobilis $51 / 7$ and that even high sodium sulphate concentrations (about $800 \mathrm{~mm}$ ) are not growth inhibitory.

\section{Cytoplasmic sulphate concentration}

The cytoplasmic concentration of sulphate was always low. Only small differences were observed at different external sulphate concentrations. Furthermore, the cytoplasmic concentration of sulphate was independent of the salinity of the growth medium $(5-15 \%$ total salts).

During experiments with reduced sulphur sources as electron donors, samples for determining the cytoplasmic sulphate concentration were taken from cultures with a sulphate concentration between $2 \cdot 0-4.3 \mathrm{mM}$. Under these conditions the cytoplasmic sulphate concentration was between 12.3 and $18.6 \mathrm{~mm}$, equivalent to an accumulation factor of about 3 - to 8 -fold. At sulphate concentrations of $2.0-3.0 \mathrm{mM}$ the cytoplasmic concentration was between 14.6 and $18.6 \mathrm{mM}$ (accumulation factor 6.2-7.6), and at sulphate concentrations of $4.0-4.2 \mathrm{mM}$ the cytoplasmic concentration was $12 \cdot 3-15 \cdot 1 \mathrm{mM}$ (accumulation factor of 2.9-3.5). Cells grown with sulphate as sole sulphur source ( $2 \mathrm{~mm}$-external sulphate concentration at $5 \%$ total salts) had a cytoplasmic concentration of $12.8 \mathrm{~mm}$-sulphate. 
Table 1. Relationship of external chloride concentrations to cytoplasmic volume and cytoplasmic chloride concentration in Ectothiorhodospira mobilis strain 51/7

\begin{tabular}{|c|c|c|c|c|}
\hline & \multicolumn{4}{|c|}{ External chloride concn (mM) } \\
\hline & $0 \cdot 4$ & 104 & 260 & 535 \\
\hline $\begin{array}{l}\text { Cytoplasmic volume } \\
{\left[\mu 1(\mathrm{mg} \text { protein })^{-1}\right]} \\
\text { Cytoplasmic chloride }\end{array}$ & $1 \cdot 20$ & $1 \cdot 39$ & $1 \cdot 33$ & $1 \cdot 25$ \\
\hline concn $(\mathrm{mM})$ & ND & 54 & 59 & 71 \\
\hline
\end{tabular}

\section{Response to chloride}

Chloride, the major anion of the natural habitat and laboratory media, could be replaced completely by sodium sulphate. Growth in the absence of added chloride was possible in media of $5 \%$ salinity over many successive transfers (experimentally determined concentration of chloride in these media was $0.4 \mathrm{mM}$ ). Growth yields under these 'chloride-free' conditions were approximately $15 \%$ below values determined under optimal growth conditions in standard medium containing about $535 \mathrm{~mm}$-chloride.

With increasing external concentrations from 104 to $535 \mathrm{~mm}$ (under iso-osmotic conditions), chloride was increasingly excluded from the cytoplasm. The cytoplasmic concentrations increased only slightly (from 54 to $71 \mathrm{mM}$ ) under these conditions (Table 1). These data indicate that cells of $E$. mobilis strain $51 / 7$ have mechanisms to maintain a relatively constant cytoplasmic concentration of chloride and to exclude chloride from the cytoplasm at high external concentrations. The ratio of cytoplasmic to external chloride determined for $E$. mobilis decreased from about 0.5 at $104 \mathrm{~mm}$ to about 0.13 at $535 \mathrm{~mm}$ external chloride.

\section{Cytoplasmic volume}

A considerable part of the total cell volume is occupied by the periplasmic space. We have determined values of about $40-50 \%$ for the periplasmic space of Ectothiorhodospira mobilis grown under standard growth conditions, which are comparable to values of approximately $38 \%$ for Vibrio costicola (Shindler et al., 1977), and 20-40\% for Escherichia coli (Stock et al., 1977).

The cytoplasmic space in late-exponential-phase cells of E. mobilis 51/7 under optimal growth conditions has been shown in a number of determinations to be $1.2-1.4 \mu \mathrm{l}$ (mg protein $)^{-1}$.

The influence of growth phase, $\mathrm{pH}$ and salinity of the growth medium on the cytoplasmic volume space in $E$. mobilis was determined. The relation between growth phase and cytoplasmic volume was determined under optimal culture conditions with $5 \%$ salinity (cultivation in a glass fermenter with a total light irradiance of $60000 \mathrm{~lx}$ ) and revealed the largest cytoplasmic volume in the exponential growth phase, but lower values in the initial lag and final stationary phase. During the initial lag phase a volume of $1.68 \mu \mathrm{l}$ (mg protein $)^{-1}$ was determined, and a maximal value of $2.73 \mu \mathrm{l}$ (mg protein $)^{-1}$ was found in the early exponential phase; this value decreased to $1.25 \mu \mathrm{l}(\mathrm{mg} \text { protein })^{-1}$ in the late exponential phase and further to $0.59 \mu \mathrm{l}(\mathrm{mg} \text { protein })^{-1}$ in the stationary phase. Similar changes were observed in cells grown at $10 \%$ salinity. These volume changes made it necessary to determine the cytoplasmic volume separately (with identical cell suspensions) in all experiments where cytoplasmic concentrations of ions had to be determined.

The $\mathrm{pH}$ dependence studies revealed the smallest cytoplasmic volume at the optimal pH (9.0) increasing at both higher and lower $\mathrm{pH}$ values (J. F. Imhoff \& A. Wohlfarth, unpublished results). At external $\mathrm{pH}$ values of $7 \cdot 0,9 \cdot 0,10 \cdot 0$ and $11 \cdot 0$, cytoplasmic volumes of $2 \cdot 4,1 \cdot 4,2 \cdot 0$ and $4 \cdot 1 \mu \mathrm{l}(\mathrm{mg} \text { protein })^{-1}$ were obtained, respectively.

The influence of the salinity on the cytoplasmic volume, determined at optimal $\mathrm{pH}$, showed smaller volumes of $E$. mobilis $51 / 7$ with increasing salinity of the medium. Cytoplasmic volumes of $1.25,1.0$ and $0.86( \pm 0.15) \mu \mathrm{l}$ (mg protein $)^{-1}$ were found at salinities of 5,10 , and $15 \%$, respectively. In contrast, two strains of $E$. halophila (strains $51 / 3$ and 51/1) had an almost constant cytoplasmic volume of $1 \cdot 2-1 \cdot 4 \mu \mathrm{l}$ (mg protein) ${ }^{-1}$ at all salt concentrations tested. 
The variation of the chloride concentration at otherwise iso-osmotic conditions ( $5 \%$ medium) had no significant influence on the cytoplasmic volume. All values were, within certain limits, around $1.25 \mu \mathrm{l}$ (mg protein $)^{-1}$. Within these limits small changes were observed with the largest cytoplasmic volume recorded at $100 \mathrm{~mm}$-chloride concentration (Table 1).

\section{DISCUSSION}

Many reports in the literature, including investigations with halophilic bacteria, relate cytoplasmic volume spaces to cell dry weight. However, dry weight determinations do not represent a valid index of the produced biomass in the presence of large amounts of salts (due to the presence of these salts and loss of organic solutes during washing with salt-free media). We have therefore related the cytoplasmic volume to the protein content, which maintains a largely constant proportion of the total organic matter over a wide range of experimental conditions (data not presented).

Some protein-related values of the cytoplasmic volume in bacteria show considerable variation. For Halobacterium halobium values of 2.5-2.75 $\mu 1$ (mg protein) ${ }^{-1}$ (Bakker et al., 1976; Michel \& Oesterhelt, 1980), and for Vibrio alginolyticus values of $3 \cdot 3 \mu \mathrm{l}$ (mg protein) ${ }^{-1}$ (Tokuda \& Unemoto, 1982) were recorded. In an unidentified moderately halophilic bacterium the space inaccessible to inulin decreased in the stationary phase and also with increasing salt concentrations (Matheson et al., 1976). These authors gave values of the space inaccessible to inulin of $4.94 \mu \mathrm{l}$ (mg protein $)^{-1}$ for exponentially growing cells, whereas for stationary-phase cultures the value was $2.56 \mu \mathrm{l}\left(\mathrm{mg}\right.$ protein) ${ }^{-1}$, when grown at low sodium concentrations (about $0.6 \mathrm{M}$-sodium). In cells grown at high sodium concentrations (about $4.4 \mathrm{M}$-sodium) the equivalent recorded values were 2.69 and $2.07 \mu \mathrm{l}(\mathrm{mg} \text { protein })^{-1}$, respectively. In view of these values a cytoplasmic volume of $1.25 \mu \mathrm{l}$ (mg protein) ${ }^{-1}$ for $E$. mobilis and of $1.2-1.4 \mu \mathrm{l}$ (mg protein) $)^{-1}$ for two strains of E. halophila, as found in this study, appears quite low. However, there are several possible explanations for this apparent disparity. Reasons may be found in different methods and marker molecules used for the determination of the cytoplasmic volume (e.g. inulin, which has been used in many investigations, does not penetrate the outer membrane of Gram-negative bacteria). Additionally, the cytoplasmic volume may be dependent on growth phase, $\mathrm{pH}$, salinity and other experimental conditions.

It has been shown by ${ }^{13} \mathrm{C}$-NMR studies that $E$. mobilis strain $51 / 7$ accumulates glycine betaine, ectoine and trehalose as compatible solutes (Imhoff, 1986; J. F. Imhoff, unpublished results), and similar results have been obtained by Galinski et al. (1985) with $E$. halochloris. If the osmotic balance by accumulation of compatible solutes is calculated on the basis of cytoplasmic compatible solute concentrations, the decrease of the cytoplasmic volume with increasing salinity of the media has to be considered. A calculation of cytoplasmic solute concentrations on the basis of the cytoplasmic volume under optimal growth conditions would result in values that are too low.

From our analyses it can be concluded that E. mobilis strain 51/7 has no requirement for high concentrations of sulphate and chloride. Analyses of the requirement for, and the cytoplasmic concentrations of, carbonates have yet to be undertaken. Carbonates are not only an essential carbon source for Ectothiorhodospira, but are also used to buffer the media. Both facts complicate a definitive proof of an ionic requirement for carbonates.

In contrast to the situation described for E. mobilis strain 51/7 the cytoplasmic concentration of chloride was found to be approximately equal to the external one in bacteria like Haloanaerobium praevalens (Oren, 1986), Halobacterium spp. (Ginzburg et al., 1970) and Alteromonas haloplanktis (Takacs et al., 1964). In the marine bacterium Vibrio alginolyticus, as in $E$. mobilis, the cytoplasmic concentration of chloride was well below the external concentration. It increased, however, considerably in $V$. alginolyticus from $71 \mathrm{~mm}$ at $0.2 \mathrm{M}-\mathrm{NaCl}$ to $584 \mathrm{mM}$ when $1.0 \mathrm{M}-\mathrm{NaCl}$ was present in the medium (Unemoto et al., 1973).

Under optimal conditions the ratio of cytoplasmic to external chloride for E. mobilis was $0 \cdot 13$; this may be compared to values of 0.14 for the moderate halophilic bacterium Vibrio costicola (Christian \& Waltho, 1962) and 0.71 for a halophilic Pseudomonas sp. (Masui \& Wada, 1973) in 
media containing $1 \mathrm{M}$-chloride, to 0.90 for Halobacterium salinarium grown at $4 \mathrm{M}-\mathrm{NaCl}$ (Christian \& Waltho, 1962), and to 0.37 for Vibrio alginolyticus with $650 \mathrm{~mm}$-chloride in the suspending medium (Unemoto et al., 1973). In Vibrio alginolyticus this ratio increased with increasing external chloride concentrations, whereas in $E$. mobilis it decreased at external concentrations of 104-535 mM-chloride. This clearly indicates that $E$. mobilis has mechanisms to exclude or to remove chloride from the cytoplasm. Whether the cytoplasmic membrane is exclusively responsible for the exclusion of chloride or whether the permeability of the outer membrane to inorganic ions also plays a role has yet to be determined. During this study we assumed identical concentrations of anions in the extracellular medium and in the periplasmic space, because no evidence is available indicating ion selectivity of the porins of Ectothiorhodospira and binding studies showed no significant binding of chloride to envelope fractions. Binding of sodium and chloride ions to soluble protein and membrane fractions was compared in the moderately halophilic $E$. halochloris, which had much higher binding capacity for sodium compared to $E$. mobilis strain $51 / 7$. Whereas the amount of bound sodium was $2130 \mathrm{nmol}$ (mg protein $)^{-1}$ in the membrane fraction and $765 \mathrm{nmol}\left(\mathrm{mg}\right.$ protein) ${ }^{-1}$ in the soluble protein fraction, the values for chloride were 38 and $25 \mathrm{nmol}$ (mg protein $)^{-1}$, respectively (J. F. Imhoff \& B. Meyer, unpublished results). In contrast to our results Coleman (1974) found that in the nonhalophilic and Gram-positive Bacillus amyloliquefaciens nearly all of the cell-associated chloride was bound to the cell envelope. Stock et al. (1977) assume a different distribution of ions in the periplasmic space compared to the external space in the Gram-negative bacteria Escherichia coli and Salmonella typhimurium. The existence of molecules in the periplasm similar to the membrane-derived oligosaccharides (MDOs), which are regarded as being responsible for the accumulation of ions in the periplasm of Escherichia coli and Salmonella typhimurium (Kennedy, 1982), has so far not been demonstrated in Ectothiorhodospira species that also have a Gram-negative type of cell wall structure.

The financial support by the Deutsche Forschungsgemeinschaft is gratefully acknowledged.

\section{REFERENCES}

Bakker, E. P., Rottenberg, H. \& Caplan, S. R. (1976). An estimation of the light-induced electrochemical potential difference of protons across the membranes of Halobacterium halobium. Biochimica et biophysica acta 440, 557-572.

BarTlETT, P. D. \& SCOOG, D. A. (1954). Colorimetric determination of elemental sulfur in hydrocarbons. Analytical Chemistry 26, 1008-1011.

Christian, J. H. B. \& Waltho, J. A. (1962). Solute concentrations within cells of halophilic and nonhalophilic bacteria. Biochimica et biophysica acta 65 , 506-508.

Cohen, S., Oren, A. \& ShIlo, M. (1983). The divalent cation requirement of Dead Sea halobacteria. Archives of Microbiology 136, 184-190.

Coleman, G. (1974). Nature of the major inorganic ions concentrated during growth of Bacillus amyloliquefaciens. Journal of General Microbiology 84, 297-302.

DoDgson, K. S. (1961). Determination of inorganic sulfate in studies on the enzymatic and nonenzymatic hydrolysis of carbohydrate and other sulfate esters. Biochemical Journal 78, 312-319.

DREws, G. (1981). Rhodospirillum salexigens spec. nov., an obligatory halophilic phototrophic bacterium. Archives of Microbiology 130, 325-327.

Galinski, E. A., Pfeiffer, H.-P. \& TrüPer, H. G. (1985). 1,4,5,6-Tetrahydro-2-methyl-4-pyrimidinecarboxylic acid. A novel cyclic amino acid from halophilic phototrophic bacteria of the genus Ecto- thiorhodospira. European Journal of Biochemistry 149, 135-139.

GinzburG, M., SACHS, L. \& GinzbURG, B. Z. (1970). Ion metabolism in a Halobacterium. I. Influence of age of culture on intracellular concentrations. Journal of General Physiology 55, 187-207.

IMHOFF, J. F. (1986). Osmoregulation and compatible solutes in eubacteria. FEMS Microbiology Reviews $39,57-66$.

IмноFF, J. F. (1988a). Halophilic phototrophic bacteria. In Halophilic Bacteria, pp. 85-108. Edited by F. Rodriguez-Valera. Boca Raton: CRC Press.

IMHOFF, J. F. (1988b). Anoxygenic phototrophic bacteria. In Methods in Aquatic Bacteriology, pp. 207-240. Edited by B. Austin. Chichester: John Wiley.

IMHOFF, J. F. \& TRÜPER, H. G. (1977). Ectothiorhodospira halochloris sp. nov., a new extremely halophilic phototrophic bacterium containing bacteriochlorophyll $b$. Archives of Microbiology 114, 115-121.

IMHOFF, J. F., SAHL, H. G., Soliman, G. S. H. \& TRÜPER, H. G. (1979). The Wadi Natrun: chemical composition and microbial mass developments in alkaline brines of eutrophic desert lakes. Geomicrobiology Journal 1, 219-234.

IMHOFF, J. F., TINDall, B. J., GRant, W. D. \& TRÜPER, H. G. (1981). Ectothiorhodospira vacuolata sp. nov., a new phototrophic bacterium from soda lakes. Archives of Microbiology 130, 238-242.

KENNEDY, E. P. (1982). Osmotic regulation and the 
biosynthesis of membrane-derived oligosaccharides in Escherichia coli. Proceedings of the National Academy of Sciences of the United States of America 79, 1092-1095.

MASUI, M. \& WADA, S. (1973). Intracellular concentrations of $\mathrm{Na}^{+}, \mathrm{K}^{+}$, and $\mathrm{Cl}^{-}$of a moderately halophilic bacterium. Canadian Journal of Microbiology 19, 1181-1186.

Matheson, A. T., Sprott, G. D., McDonald, I. J. \& TESSIER, H. (1976). Some properties of an unidentified halophile: growth characteristics, internal salt concentration, and morphology. Canadian Journal of Microbiology 22, 780-786.

MiChEL, H. \& OESTERHELT, D. (1980). Electrochemical proton gradient across the cell membrane of Halobacterium halobium: effect of $\mathbf{N}, \mathbf{N}^{\prime}$-dicyclohexylcarbodiimide, relation to intracellular adenosine triphosphate, adenosine diphosphate and phosphate concentration, and influence of the potassium gradient. Biochemistry 19, 4607-1614.

Mullakhanbhai, M. F. \& LaRSEN, H. (1975). Halobacterium volcanii spec. nov., a Dead Sea halobacterium with a moderate salt requirement. Archives of Microbiology 104, 207-214.

Nissen, H. \& DUNDAS, I. D. (1984). Rhodospirillum salinarum sp. nov., a halophilic photosynthetic bacterium isolated from a Portuguese saltern. Archives of Microbiology 138, 251-256.

NovoZamsKy, I. \& vaN ECK, R. (1977). Total sulfur determination in plant material. Zeitschrift für Analytische Chemie 286, 367-368.

OREN, A. (1986). Intracellular salt concentrations of the anaerobic halophilic eubacteria Haloanaerobium praevalens and Halobacteroides halobius. Canadian Journal of Microbiology 32, 4-9.

PACHMAYR, F. (1960). Vorkommen und Bestimmung von Schwefelverbindungen im Mineralwasser. Dissertation, University of München, FRG.

RodRiguez-VAlera, F., Ventosa, A., Juez, G. \& IMHOFF, J. F. (1985). Variation of environmental features and microbial populations with salt concentrations in a multi-pond saltern. Microbial Ecology 11, 107-115.

RotTENBerG, H. (1979). The measurement of membrane potential and $\mathrm{pH}$ in cells, organelles and vesicles. Methods in Enzymology 55, 547-569.

ShINDleR, D. B., Wydro, R. M. \& Kushner, D. J. (1977). Cell-bound cations of the moderately halophilic bacterium Vibrio costicola. Journal of Bacteriology 130, 698-703.

SolimaN, G. S. H. \& TRÜPER, H. G. (1982). Halobacterium pharaonis sp. nov., a new extremely haloalkaliphilic archaebacterium with low magnesium requirement. Zentralblatt für Bakteriologie, Mikrobiologie und Hygiene (Abteilung I, Originale ) C3, 318329.

Stock, J. B., Rauch, B. \& Roseman, S. (1977). Periplasmic space in Salmonella typhimurium and Escherichia coli. Journal of Biological Chemistry 252, 7850-7861.

Takacs, F. P., Matula, T. I. \& Macleod, R. A. (1964). Nutrition and metabolism of marine bacteria. XIII. Intracellular concentrations of sodium and potassium ions in a marine pseudomonad. Journal of Bacteriology 87, 510-518.

TOKUDA, H. \& UNEMOTO, T. (1982). Characterization of the respiration-dependent $\mathrm{Na}^{+}$pump in the marine bacterium Vibrio alginolyticus. Journal of Biological Chemistry 257, 10007-10014.

TRÜPER, H. G. (1968). Ectothiorhodospira mobilis Pelsh, a phototrophic bacterium depositing sulfur outside the cells. Journal of Bacteriology 95, 1910-1920.

Unemoto, T., Tsuruoka, T. \& Hayashi, M. (1973). Role of $\mathrm{Na}^{+}$and $\mathrm{K}^{+}$in preventing lysis of slightly halophilic Vibrio alginolyticus. Canadian Journal of Microbiology 19, 563-571.

URBAN, P. J. (1961). Colorimetry of sulfur anions. I. An improved colorimetric method for the determination of thiosulfate. Analytical Chemistry 179, 415-422. 